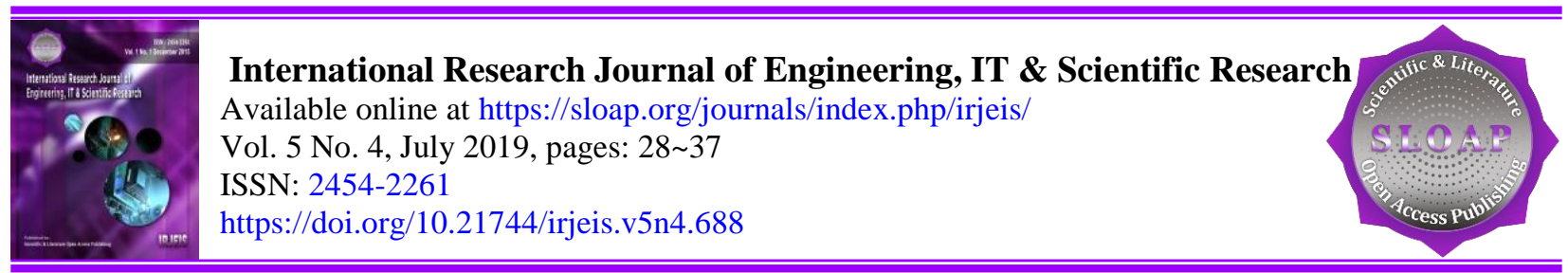

\title{
Developing Ergonomics-Based Practice System to Improve Students' Typing Skills
}

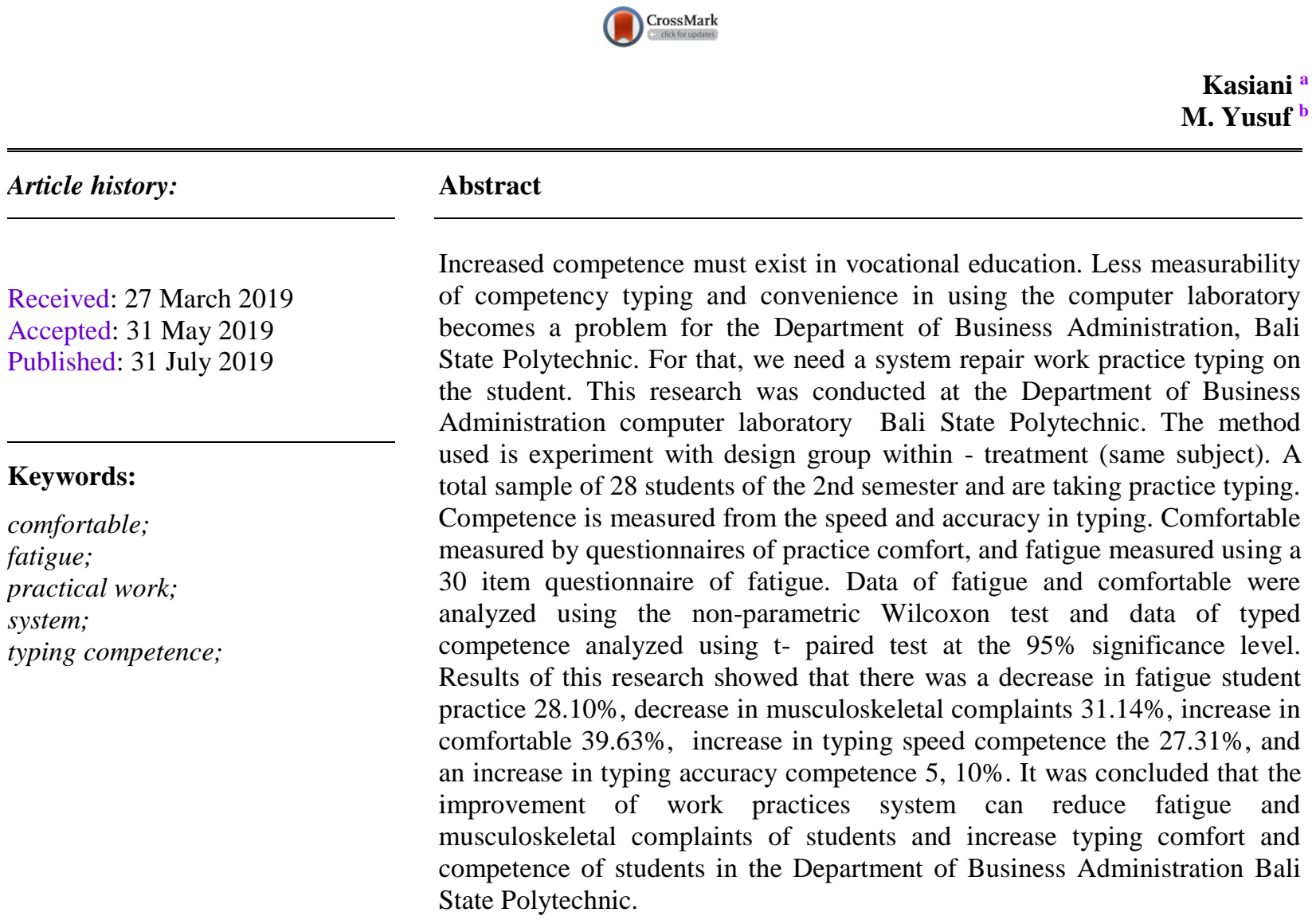

2454-2261 ${ }^{\circledR}$ Copyright 2019. The Author. This is an open-access article under the CC BY-SA license (https://creativecommons.org/licenses/by-sa/4.0/) All rights reserved.

\section{Author correspondence:}

Kasiani,

Lecturer Staff, Politeknik Negeri Bali

Email address: aniksuhantono@gmail.com

${ }^{\text {a }}$ Politeknik Negeri Bali, Denpasar, Indonesia

${ }^{\mathrm{b}}$ Politeknik Negeri Bali, Denpasar, Indonesia 


\section{Introduction}

Increasing competence is the goal of vocational education. In vocational education, the activities must be systematic and structured. Lectures, practice, professional training programs, specializations, and the like need to be held well and continuously, so that graduates who have high competence are ready to work. Likewise, the programs at Bali State Polytechnic, especially the Business Administration Department, meet the vision of the Department, namely: To become a leading study program in producing professional graduates in the field of business administration and secretary, who have the knowledge and skills appropriate to the demands of technology and industry with international quality competitiveness. For this reason, it is necessary to organize education which leads to the realization of this vision (Macías et al., 2018; Ginaya et al., 2018).

One of the courses taught in the Business Administration Department is typing speed. This course belongs to the adeptness course group (MKB). The purpose of this course is to improve students' typing skills needed by a secretary or administrative employee. In the world of business or office, such as Hotels, Travel, and Clothing Companies, be it limited liability companies, Limited Partnership, Firma, and government agencies such as Education, Social or Economics Affairs, being able to type professionally is needed both for a secretary or an office employee. This is because typing is the basis for keyboard mastery (Sulastri, 2014).

The keyboard mastery is directed at fostering and developing typing skills, but the completeness in typing is not only determined by the computer but involves external conditions (excluding typists) such as chairs used, computer desks, stopwatches (tools for measuring speed and accuracy), paper used, physical work environment, typing fatigue exercise, sitting attitude while typing, placement of the script, and the typists being in a state of physical and spiritual health, mental readiness for typing, and concentration at the time of typing.

Problems that occur when practicing on typing courses include: students' typing speed is not yet optimal, many typing errors occur, chairs are not in accordance with student body size so that fatigue often occurs, a lot of students do not meet the correct requirements when it comes comes to sitting (such as one leg resting on the knee, holding a college bag when typing, not leaning on the back of a chair), the typing script is not placed on the right side of the computer but on the left so it takes time because the typing script always shifts erratically, the eye view is not fixed on the typing script but precisely on the keyboard, the temperature of the practice room is sometimes hot because the $\mathrm{AC}$ is out of order, and so on.

These problems will have an impact on the lack of achievement of competencies in typing. For this reason, there is a need for corrective steps so that these problems are resolved and typing competencies can be achieved. Preliminary research found that the minimum target to be achieved in the typing practice is the speed for the Indonesian language text is 25 words per minute and $98 \%$ accuracy, while the English language text is targeted at 20 words per minute with an accuracy of $98 \%$ (Workshop in Business Administration, 2012).

The solution steps of these problems include the improvement of the system in typing practice based on ergonomic rules. Among the rules of ergonomics is making people work more effectively, comfortably and productively (HSE, 2013). In terms of subjects (students), there needs to be an improvement in sitting attitude so that it is in accordance with the standard work sitting posture. In terms of the equipment used: work chairs must be in accordance with student anthropometry, computer desks according to needs, computer light does not cause glare, use of text holders and students rest their feet under the table. In terms of work arrangements, there are a need for practical SOP and more suitable Job sheet practices.

Therefore, this research is necessary to improve the practical work system by improving student sitting work posture, the use of text handles, the use of typing SOP and typing practice worksheets, the arrangement of practical work environments (AC and lighting), and measuring student perceptions of typing convenience, and conducting competency tests.

\section{Materials and Methods}

This research is experimental research with group design within - treatment (same subject). The number of samples was 27 second-semester students and were taking typing practices. Improvement of typing practice system based on ergonomics, namely in the form of working environment settings (air conditioning and lighting), using text holder, new worksheets, improvement of sitting work posture, and use of practice SOP. Competence was measured by speed and accuracy in typing. Comfort was measured by a practical comfort questionnaire, and Fatigue was measured using a questionnaire of 30 items of fatigue. Fatigue and comfort data were analyzed using the Wilcoxon 
test, a non-parametric statistics and typing competency data were analyzed using t-test $\mathrm{t}$ at a significance level of $95 \%$.

\section{Results and Discussions}

\subsection{Characteristics of the Subjects}

The number of samples in this study was 27 students. The results of the descriptive analysis of the characteristics of the research subjects are presented in Table 1 below.

Table 1

Physical characteristics of the subjects

\begin{tabular}{cllll}
\hline No & Variable & Mean & SD & Range \\
\hline 1 & Age (year) & 19,3 & 1,2 & $17,0-20,0$ \\
2 & Body weight $(\mathrm{kg})$ & 58,3 & 2,3 & $55,0-70,5$ \\
3 & Body height $(\mathrm{cm})$ & 166,3 & 2,8 & $155,0-173,0$ \\
4 & BMI $\left(\mathrm{Kg} / \mathrm{m}^{2}\right)$ & 21,7 & 1,1 & $20,1-23,6$ \\
\hline
\end{tabular}

Note: BMI: Body Mass Index; SD: Standard Deviation

The table above shows that the mean age of the subjects was $19,3 \pm 1,2$ years, the mean body weight was $58,3 \pm 2,3$ $\mathrm{kg}$, mean body height was $166,3 \pm 2,8 \mathrm{~cm}$, and mean BMI was $21,7 \pm 1,1 \mathrm{~kg} / \mathrm{m}^{2}$. Their age, body weight, and height, and body mass index can be categorized as normal. The age range is the optimal condition for students to study or work so that the learning system needs to be enhanced to improve learning outcomes and productivity.

\subsection{Analysis of Working Environment Conditions}

The working environment conditions were measured based on microclimate conditions in the practice room. The data were tested for normality using the Kolmogorov-Smirnov test and the results of the work environment data in the P0 and P1 groups were normally distributed (P 5 0.05). To find out whether each treatment provided the same or different conditions, a paired-sampled t-test was performed. The results of the analysis of working environment conditions during this research are presented in Table 2 below.

Table 2

Results of Work Environment Analysis

\begin{tabular}{|c|c|c|c|c|c|c|c|}
\hline \multirow{2}{*}{ No } & \multirow{2}{*}{ Variable } & \multicolumn{2}{|c|}{ P0 } & \multicolumn{2}{|c|}{ P1 } & \multirow{2}{*}{$\mathrm{t}$} & \multirow{2}{*}{$\mathrm{P}$} \\
\hline & & Mean & $\mathrm{SD}$ & Mean & $\mathrm{SD}$ & & \\
\hline 1 & Wet temperature $\left({ }^{\circ} \mathrm{c}\right)$ & 27,79 & 1,21 & 24,03 & 0,27 & $-0,132$ & 0,028 \\
\hline 2 & Dry temperature $\left({ }^{\circ} \mathrm{c}\right)$ & 28,22 & 1,35 & 26,87 & 0,65 & $-1,058$ & 0,015 \\
\hline 3 & Relative humidity (\%) & 74,32 & 1,51 & 75,02 & 1,27 & 0,807 & 0,612 \\
\hline 4 & Lighting intensity (Lux) & 425,46 & 23,41 & 421,28 & 20,27 & $-7,050$ & 0,168 \\
\hline 5 & Sound intensity (dBA) & 70,23 & 4,02 & 69,52 & 0,39 & $-0,563$ & 0,720 \\
\hline
\end{tabular}

Note: $\mathrm{SD}=$ Standard Deviation

Table 2 shows that there was a significant difference in the environmental conditions of the practice room at wet and dry temperatures $(\mathrm{p}<0.05)$. However, there was no significant difference in the relative humidity, lighting intensity, and sound intensity $(\mathrm{p}>0.05)$. The condition of the room temperature at P0 was hotter than at P1; this was because at P1 there was already an SOP of practice activities that states that the AC must be turned on before the practice starts, the room temperature should be adjusted during the practice activities, and maintenance on the equipment in the practice room should be done, so the practice activities are more comfortable.

Kasiani, -, \& Yusuf, M. (2019). Developing ergonomics-based practice system to improve students' typing skills. International Research Journal of Engineering, IT \& Scientific Research, 5(4), 28-37. https://doi.org/10.21744/irjeis.v5n4.688 
For students who study in a room, the suitable temperature in a tropical area should be $22-27^{\circ} \mathrm{C}$. Whereas relative humidity, light intensity, and sound intensity did not differ significantly between P0 and P1. Comfortable humidity is at $70-80 \%$ while the need for light intensity to read or activity that requires accuracy is $300-700$ lux and a non-noisy atmosphere (Manuaba, 2006; Zambrano et al., 2018; Sadiyani, 2018). The noise threshold is 85 dB (BSN, 2004).

\subsection{Analysis of General Fatigue and Muskuloskeletal Complaints}

Before the significance test was carried out because of the treatment effect it needed to be seen in advance the comparability of the initial conditions for general fatigue and musculoskeletal complaints of students who were the subjects of the study. Comparability was done to ascertain whether the difference in general fatigue and musculoskeletal complaints was due to the effect of treatment or there were other factors that influence them.

The statistical test used in this case was the Wilcoxon test. The results of the analysis are presented in Table 3 below.

Table 3

General Fatigue Comparability and Musculoskeletal Complaints

\begin{tabular}{lllllll}
\hline \multirow{2}{*}{ Variable } & \multicolumn{2}{c}{ P0 } & \multicolumn{2}{c}{ P1 } & Z & P \\
& Mean score & SD & Mean score & SD & & \\
\hline General fatigue & 34,72 & 2,51 & 35,03 & 1,54 & 0,171 & 0,108 \\
Musculoskeletal complaints & 36,47 & 3,12 & 35,57 & 2,95 & $-1,104$ & 0,217 \\
\hline
\end{tabular}

The initial condition (pre) was $\mathrm{p}>0.05$. This indicates that the initial conditions were not significantly different and can be considered the same or have the same effect on each treatment.

The effects of treatment on general fatigue and musculoskeletal complaints were analyzed by performing different tests of significance in each treatment (P0 and P1). This significance difference test was carried out using the Wilcoxon test. The results of the analysis can be seen in Table 4 below.

Table 4

Results of the analysis of General Fatigue and Musculoskeletal Complaints

\begin{tabular}{|c|c|c|c|c|c|c|}
\hline \multirow{2}{*}{ Variable } & \multicolumn{2}{|c|}{ P0 } & \multicolumn{2}{|c|}{ P1 } & \multirow{2}{*}{$\mathrm{Z}$} & \multirow{2}{*}{$\mathrm{P}$} \\
\hline & Mean score & SD & Mean score & SD & & \\
\hline General fatigue & 58,50 & 3,22 & 42,06 & 2,13 & $-33,276$ & 0,000 \\
\hline Musculoskeletal complaints & 74,32 & 4,17 & 51,18 & 3,95 & $-67,244$ & 0,000 \\
\hline
\end{tabular}

From Table 4 it can be stated that the final condition for general fatigue and musculoskeletal complaints yielded $\mathrm{p}=$ 0,000 or $\mathrm{p}<0.05$. This shows that there is a significant difference between period 1 and period 2 . If seen from the mean score both in general fatigue and complaints of skeletal muscles, there was a decrease in scores from P0 to P1. The general fatigue score dropped by $28.10 \%$, while the skeletal muscle complaints score decreased by $31.14 \%$. This decrease in muscle and fatigue complaints was predicted because students had implemented practice SOP well so that ergonomic repairs were made, using text holder, with comfortable environmental conditions. Improvement of work attitude (students' sitting attitude) should be done so that work (practice) will be more comfortable so as to reduce fatigue and complaints of skeletal muscles (Kroemer \& Grandjean, 2009). The natural sitting position would provide more productive comfort and work (Yusuf et al., 2017).

\subsection{Analysis of Typing Practice Comfort}

The comfort of typing practice was measured using a questionnaire both at P0 and on P1. The difference test between P0 and P1 comfort scores was analyzed using the Wilcoxon test. The results of the analysis are presented in Table 5 below. 
Table 5

Results of Analysis of Typing Practice Comfort

\begin{tabular}{|c|c|c|c|c|c|c|}
\hline \multirow{2}{*}{ Variable } & \multicolumn{2}{|c|}{ P0 } & \multicolumn{2}{|c|}{ P1 } & \multirow{2}{*}{$\mathrm{Z}$} & \multirow{2}{*}{$\mathrm{P}$} \\
\hline & Mean score & SD & Mean score & SD & & \\
\hline Comfort level & 42,09 & 3,92 & 58,77 & 4,17 & 11,207 & 0,000 \\
\hline
\end{tabular}

Table 5 shows that there were significant differences $(\mathrm{p}<0.05)$ between the comfort scores at P0 and P1. Judging from its mean score, P1 gives higher comfort than P0 of $39.6 \%$.

Improvement of services in educational institutions is urgently needed to ensure continuous availability of quality education in accordance with national standards, for example, services to students' practice need to be improved so that comfort and learning objectives are well achieved (Masri et al., 2011). Comfort in the learning process will improve the ability of students to absorb knowledge and do assignments, hence students will be more productive. This is in accordance with the rules of ergonomics, namely to make people more comfortable and productive in their work (Dul \& Weerdmeester, 2008).

\subsection{Analysis of Typing skills}

Typing skills refer to students' competence in the practice of typing as measured by speed and accuracy in typing. Speed and accuracy were measured by the following formula :

$$
\text { Speed }=\frac{\text { Total letters }}{5 \text { letters }}=\frac{\text { Total } \text { words }}{\text { Time }(5 \text { mins })}
$$

1 word was considered 5 letters

$$
\text { Speed }=\frac{\text { Total } \text { words }(5 \text { mins })-\text { errors }}{\text { Total } \text { words }(5 \text { mins })} \times 100 \%
$$

The subjects typed the text that had been provided in two languages, Indonesian and English. Data on the typing speed and accuracy obtained in this study were tested its normality with the Shapiro Wilk test. From the results of the normality test, it was found that the data speed and accuracy of typing were normally distributed ( $p>0.05)$. The different analysis of the significance of this typing skills data between P0 and P1 was analyzed using the pairedsamples t-test presented in Table 6 below.

Table 6

\begin{tabular}{|c|c|c|c|c|c|c|}
\hline \multirow{2}{*}{ Variable } & \multicolumn{2}{|c|}{ P0 } & \multicolumn{2}{|c|}{ P1 } & \multirow{2}{*}{$\mathrm{t}$} & \multirow{2}{*}{$\mathrm{P}$} \\
\hline & Mean score & SD & Mean score & SD & & \\
\hline Typing speed & 23,91 & 2,925 & 30,44 & 2,515 & 6,685 & 0,000 \\
\hline Typing accuracy & 94,26 & 2,795 & 99,07 & 3,025 & 4,0455 & 0,000 \\
\hline
\end{tabular}

Results of analysis typing competence

From Table 6 it can be stated that the speed and accuracy of typing between P0 and P1 yielded a value of p <0.05. This indicates that there was a significant difference in typing skills between P0 and P1. P1 gives a mean score that was larger than P0. Judging from its mean value, typing speed increased by $27.31 \%$ and typing accuracy increased by $5.10 \%$.

Competence is one of the important factors in the field of education (Higher Education). By having competencies that are in accordance with the field of study, the quality of students will be recognized by the industry as a market for college graduates. Providing students with valued competencies can be planned from the beginning of the semester if students have/know the tools and parameters used in obtaining competency weights for each field of competence (Firmin et al., 2016).

Kasiani, -, \& Yusuf, M. (2019). Developing ergonomics-based practice system to improve students' typing skills. International Research Journal of Engineering, IT \& Scientific Research, 5(4), 28-37. https://doi.org/10.21744/irjeis.v5n4.688 


\section{Conclusion}

On the basis of the analysis of the data for the present study, the following conclusion could be drawn.

a) improvement of ergonomics-based practicum system can reduce student fatigue in general fatigue and complaints of skeletal muscles in typing practice at the Bali State Polytechnic Business Administration.

b) Improvement of the ergonomics-based practice system can improve the competence of students at the Bali State Polytechnic, Business Administration Department.

\section{Suggestions}

The results of this study indicate that by improving the typing practice system based on ergonomics in the form of work environment settings (air conditioning and lighting), using text holder, new worksheets, and using practice SOP can reduce fatigue, improve typing comfort, and improve student typing skills. Thus, it is recommended that:

a) To students, in the practice of typing sitting posture is to be paid attention to, text holder should be used, the temperature should be adjusted and ventilation of the room should create comfort, and hence they do not feel fatigued quickly.

b) The policymakers of the education sector should always think about improving student skills including typing skills for the achievement of the educational goals.

c) The results of this study can be used as a reference for similar research and yet further research on improving student typing skills is needed.

\section{Conflict of interest statement and funding sources}

The authors declared that they have no competing interest.

\section{Statement of authorship}

The authors have a responsibility for the conception and design of the study. The authors have approved the final article.

\section{Acknowledgments}

The authors would like to thank the Editor of IRJEIS for their valuable time, support, and advice in completing the current study. 


\section{References}

BSN. (2004). Threshold value for working condition under heat, noise, vibration hand-arm, and ultraviolet sun light exposure, SNI 16-7063-2004. Jakarta: Badan Standarisasi Nasional.

Dul, J., \& Weerdmeester, B. (2008). Ergonomics for beginners: A quick reference guide Third Edition.

Firmin, M. W., Lucius, J. E., \& Johnson, S. (2009). Student perspectives of competition: A qualitative analysis. American Journal of Business Education, 2(2), 7. https://doi.org/10.19030/ajbe.v2i2.4031

Ginaya, G., Rejeki, I. N. M., \& Astuti, N. N. S. (2018). The effects of blended learning to students' speaking ability. International Journal of Linguistics, Literature and Culture, 4(3), 1-14.

Kroemer, K. H. (2008). Fitting the human: Introduction to ergonomics. CRC Press.

Macías, EIP, Cedeño, HAC, \& Chávez, GMR (2018). Importance of Improving Resilience in Teaching-Learning Process of Students with Disabilities. International Research Journal of Management, IT and Social Sciences, 5 (2), 120-128.

Manuaba, A. (2006). Total approach is a must for small and medium enterprises to attain sustainable working conditions and environment, with special reference to Bali, Indonesia. Industrial health, 44(1), 22-26. https://doi.org/10.2486/indhealth.44.22

Masri, M., \& Fauziah, I. (2013). Analisis Mutu Layanan Laboratorium Kimia Jurusan Kimia Fakultas Matematika dan Ilmu Pengetahuan Alam UNM. CHEMICA, 12(2), 27-35.

Sachin, J. (2008). Adopting high technology automation products to infrastructre construction industry with special performance to Pune to Mumbaii.

Sadiyani, N. W. (2018). Strategy of improving student achievement in English learning through concentration approach. International Journal of Physical Sciences and Engineering, 2(1), 47-56. https://doi.org/10.29332/ijpse.v2n1.95

Sulastri, T. (2014). Analisis Mengetik Cepat 10 Jari Menggunakan Teknologi Komputer Berbasis Aplikasi Software Rapidtyping. Jurnal Komputer Bisnis, 4(2).

Workshop Jurusan Administrasi Niaga. (2012). Review Kurikulum dan Peningkatan Kompetensi Mahasiswa. Denpasar.

Yusuf, M., Santiana, M., \& Lokantara, W. D. (2018, May). Improvement of work posture to decrease musculoskeletal disorder and increase work productivity jewelry worker in bali. In Proceedings (Vol. 1, No. 1, pp. 242-247).

Zambrano, R. L. B., Villamil, K. V. S., \& Cantos, K. L. G. (2018). Resilience and Personal Improvement of Students with Motor Disabilities. International Research Journal of Management, IT and Social Sciences, 5(2), 96-103.

\section{Biography of Authors}

\begin{tabular}{|l|l|}
\hline & Kasiani, S.E., M.Si \\
Masters of Business Administration \\
Experts in the field of economic management and business administration \\
Email: aniksuhantono@gmail.com
\end{tabular}

Kasiani, -, \& Yusuf, M. (2019). Developing ergonomics-based practice system to improve students' typing skills. International Research Journal of Engineering, IT \& Scientific Research, 5(4), 28-37. https://doi.org/10.21744/irjeis.v5n4.688 